\title{
NOTES ON THE NASAL TRACT COMPLEX OF THE BOUTU, INIA GEOFFRENSIS (DE BLAINVILLE, 1817) (CETACEA, PLATANISTIDAE)
}

\author{
by \\ E. J. SCHENKKAN \\ Zoological Laboratory, University of Amsterdam, The Netherlands
}

\begin{abstract}
The anatomy of the nasal passage of three specimens of the Boutu has been studied.

The various diverticula appear to be aberrant from those described for other Platanistidae.

The vestibular airsac system has developed into one enormous diverticulum. Except for a narrow region caudal to the blowhole, the total maxillary area caudal to the orbits is covered by this somewhat dome-shaped airsac system.

The dorsal and rostral aspects of the vestibular system are strikingly symmetrical as are also the deeper parts of the nasal passage.

The caudal parts of the nasofrontal diverticula are well developed, rostral parts are tubular and relatively small. Accessory air sacs are lacking and the premaxillary diverticula are broad, but their lumina rostral to the bony nares are nearly completely filled with dorsal swellings of the premaxillary bones when the former are deflated.
\end{abstract}

\section{HISTORICAL REVIEW AND INTRODUCTION}

The ancient Greeks were aware of the mammalian characteristics in dolphins and whales, but it was not until the last decades of the seventeenth century that zoological interest grew beyond mere curiosity. The great proliferation in the study and demonstration of the anatomy, not only of Man but of a great variety of species, resulted in several reports dealing with the morphology of the Common or Harbour Porpoise, Phocoena phocoena (Linnaeus, 1758) e.g. those of Ray (1671), Major (1672) and Tyson (1680).

In one of the first anatomical studies on a cetacean, "An account of the dissection of a porpess", John Ray (1671) included a brief description of the nasal apparatus in which he tried to provide a functional interpretation of some of the features. He noted that the trachea was short and the larynx was elongated, terminating in what he called (: 2276) "a nob at the end like an old fashioned Ewer". More distally, he found a sphincter above the apex of the laryngeal spout and a "glandulous flesh" lining of the bony nares. From here, above the level of the skull, Ray (1671: 2277) observed "six blind holes having no out-let; four tending towards the snout; two above the valve that stops the nostrils [now called vestibular diverticula c.q. nasal plugs]; and two beneath it [premaxillary diverticula]; two tending towards the brain [caudal section of the nasofrontal airsacs], having a long but narrow cavity for the use of smelling, as I [Ray] conjecture, though opening the brain I could find neither olfactory nerves nor processus mammillares".

Since that time, amongst other papers dealing with cetacean anatomy, more detailed studies of the facial region have appeared, see e.g. Hunter (1787), Von Baer (1826), Sibson (1848), Murie (1870, 1871, 1873), Gruhl (1911), Hanke (1914) and Huber $(1930,1934)$. Detailed data concerning uncommon species were published, e.g. Burmeister (1867), Watson \& Young (1879), Pouchet \& Beauregard (1885), Carlsson (1888), Benham (1901), Le Danois (1910, 1911), Beddard (1915, 1919), Kernan \& Von Schulte (1918) and Huber (1934).

It had been known since classical times that cetaceans could produce and perceive sounds having a communicative meaning. The discovery of echolocation as used by bats, see e.g. Griffin \& Galambos (1940, 1941), Dijkgraaf (1943) and Griffin (1958) together with observations about the sensitivity of dolphins to sounds of high frequency (Fraser, 1947), led to the assumption that in cetaceans a similar mechanism to that in bats might exist for emission and perception of high frequency sounds. In 1961, Norris et al. most elegantly demonstrated echolocation by blindfolding a Bottle-nosed Dolphin, Tursiops trun- 
catus (Montagu, 1821). From that time the list of species found to produce sounds of high frequency increased, see e.g. Caldwell, Prescott \& Caldwell (1966) and Evans, Sutherland \& Beil (1964). This phenomenon has augmented the interest in the morphology of various facial structures in an attempt to understand the mechanisms involved in the production, transmission, modulation, emission, and perception of these sounds.

The morphology of the sound perception structures has been dealt with by Fraser \& Purves $(1954,1960)$, Reysenbach de Haan (1956), Purves (1966), Purves \& Van Utrecht (1963), and more recently by Fleischer (1973), whilst others explored the nasal passage and adjacent structures in order to find the structures responsible for monitoring, transmitting, beaming and emitting of the various sounds, e.g. Lawrence \& Schevill (1956), Moris (1969), Norris (1969) and Norris et al. (1971). Analysis of sounds and the pattern of emission had been dealt with by Evans \& Prescott (1962), Caldwell, Caldwell \& Evans (1966) and Norris \& Evans (1967). It would seem that the importance of the character of the echoes that are reflected from the surface of various structures has been underestimated (Van der Ree, Kamminga, pers. comm.).

In most terrestrial mammals the source of sounds is located in the larynx where air is passed through laryngeal structures. The vibrations of the air and laryngeal structures are easily transmitted to air-filled cavities for inforcement by resonance and thence to the surrounding air, since there is no large change in density in the sound path. Airborne sounds as emitted by terrestrial mammals are useless to aquatic mammals since they cannot be transmitted economically to the surrounding water as there is over $99 \%$ reflection of the energy at any air-water interface. In cetaceans where vocal cords are lacking, other laryngeal structures such as thyroarytenoid or aryepiglottic folds could subserve the function of phonation, as is found in many other terrestrial mammals, though special modifications are required to enable the vibrations to be transmitted to the surrounding water.

The mechanism of phonation and emission of the various sounds is still in debate, and contradicting theories concerning the site of sound sources have been postulated. In view of these conflicting theories, comparative studies on the morphology of the nasal tract have been undertaken by Schenkkan $(1971,1972,1973)$ and by Mead (1972, 1975). The variation in the morphology of the nasal tract within the suborder Odontoceti is so great, that, concerning the uniformity of the sounds used in the various species, its alleged function in this phonatory system is unlikely.

The morphology of the nasal apparatus in the family Platanistidae has been dealt with to some extent by the descriptions of Anderson (1878), Purves \& Pilleri (1973) for the genus Platanista Wagler, 1830; Burmeister (1867), Schenkkan (1972) and Mead (1972, 1975) for Pontoporia blainvillei (Gervais \& d'Orbigny, 1844); Hinton (1936) for Lipotes vexillifer Miller, 1918; while Mead (1975) published a preliminary note on Inia geoffrensis (De Blainville, 1817).

\section{MATERIAL AND DESCRIPTION}

The material for the present study consisted of: 1. A formalin preserved head of Inia geoffrensis borrowed by Dr. P. J. H. van Bree from Dr. Edgardo Mondolfi, Caracas, Venezuela, for taxonomic studies. Van Bree and Mondolfi allowed me to dissect the head.

2. A complete deepfrozen specimen of Inia geoffrensis, donated by Dr. C. Pedro Trebbau of Caracas, Venezuela, to the Institute of Taxonomic Zoology (Zoölogisch Museum) of the University of Amsterdam (coll. no. ZMA 16.936). Van Bree kindly allowed me to dissect the head of this specimen as well. From this head a silicone cast was made from the nasal tract.

3. The head of the albino Inia geoffrensis that unfortunately died in the Duisburg Zoo was kindly offered for dissection by Dr. W. Gewalt. Dissection of this specimen was made possible by the very kind hospitality of Prof. Dr. M. Klima and his staff, Morphological Centre of J.W. Goethe University at Frankfurt/Main.

As usual in most odontocetes, the blowhole is found at the apex of the head, slightly disposed left of the midline. Contrary to what is found in most other species, the less crescentic slit is directed with its concavity in a caudal direction. Exploring the nasal passage from the blowhole downwards, the orifice widens slightly to form the vestibule, the lumen of which in its resting state is almost completely filled with the lips of 




Fig. 1. Dorsal aspect of the skull of Inia geoffrensis (Zoological Museum Amsterdam coll. no. 16.936) demonstrating the position and shape of the vestibular system by means of a mounted silicone cast of the nasal passage. Photograph: S. van Mechelen.

CSM = supramaxillary crest; $F=$ frontal bone; $F M=$ foramen magnum; $M=$ maxillary bone; $O=$ occipital bone; $O R=$ orbit; $P M=$ premaxillary bone; $S V L=$ left vestibular sac; $S V R=$ right vestibular sac. 
the blowhole. In most other odontocetes the posterior lip of the blowhole is more rigid and passes over the rostral lip. In Inia both lips are equal in density and no overlap was observed.

After removal of the skin and thin layer of blubber just around the blowhole, the most superficial layer of the maxillonasalis muscle is found lying in an almost symmetrical arrangement. This muscle layer, that controls the blowhole region, is very thin and covers the vestibular diverticula.

In Pontoporia, the right vestibular diverticulum is extended enormously, covering the whole area of the deeper layers of the right maxillonasalis muscle and even extends rostrally to the nasal passage crossing the midline (see Schenkkan, 1972). However, in odontocetes the vestibular air sacs are lateral extensions of the lateral walls of the vestibule. In Kogia breviceps (De Blainville, 1838) the situation is more complex, since the only vestibular sac is that of the right side. It possesses an enormous, complexly trabeculated, rostral component situated completely anterior to the vestibule at the left side of the head, whilst communicating with the vestibule through a narrow, horizontally situated slit in its mesial corner (Schenkkan \& Purves, 1973). Nevertheless it can still be recognized as being an extension of the lateral wall of the vestibule.

In Inia, Mead (1975) mentioned a vestibular

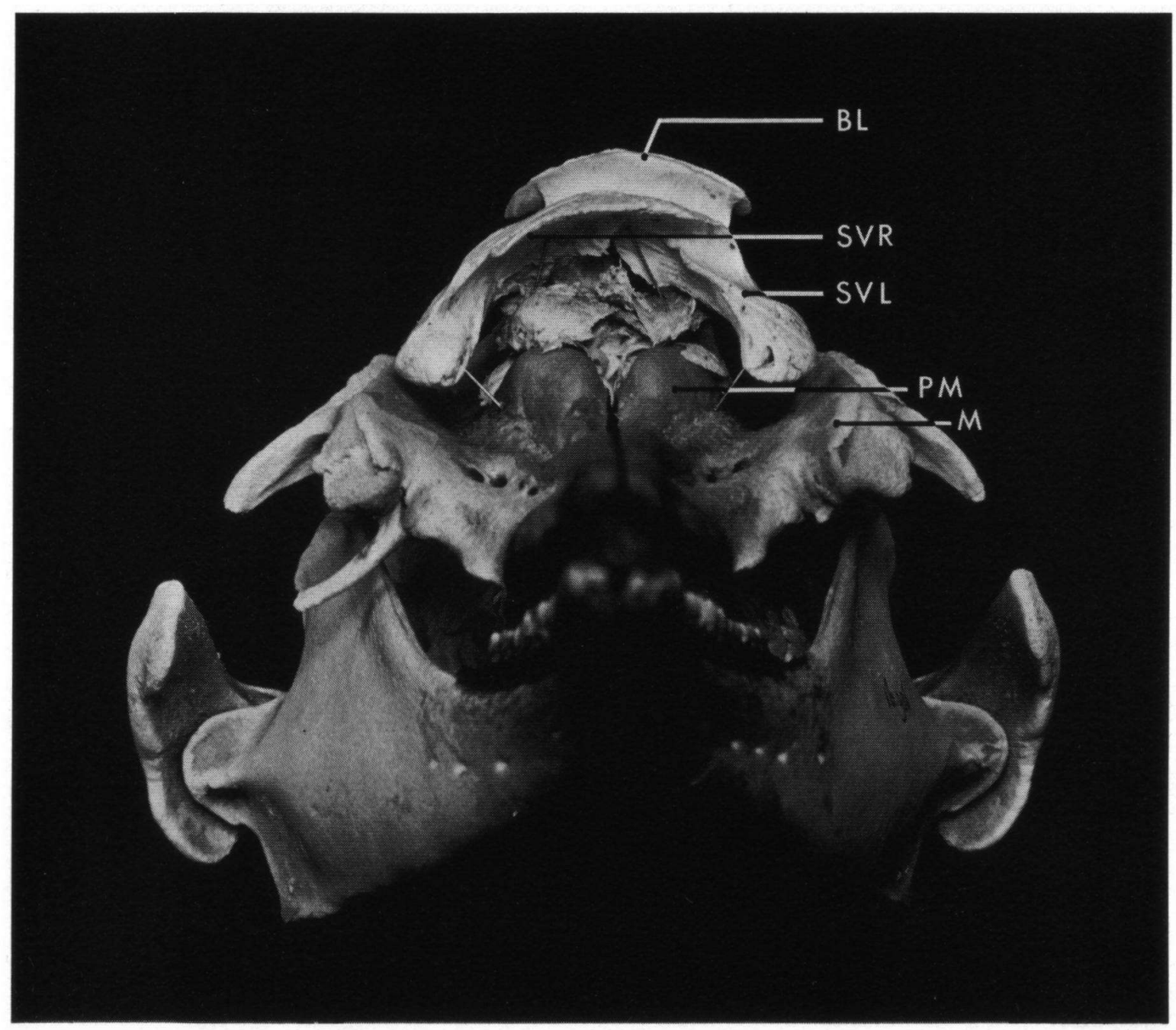

Fig. 2. Rostral aspect of the same skull and mounted cast as in fig. I, demonstrating the symmetrical orientation of the vestibular system. Photograph: S. van Mechelen.

$\mathrm{BL}=$ blowhole; $\mathbf{M}=$ maxillary bone; $\mathrm{PM}=$ premaxillary bone; $\mathrm{SVL}=$ left vestibular sac; $\mathbf{S V R}=$ right vestibular sac. 
system similar to that found in Pontoporia. However, from my dissection of the specimens of this species I cannot confirm this. At first sight, the right vestibular sac does not seem to be only an extension of the lateral wall of the vestibule, but also an enormous extension of its rostral wall over its entire width. In adult specimens it measures about $5 \mathrm{~cm}$ at the base of the extension. Rostrad to the left corner of the vestibule, this airsac arrangement slopes somewhat ventrally and surprisingly becomes continuous with the left vestibular sac. The slit through which it penetrates through the dorsal wall of the left vestibular sac is bordered dorsally by a gristly strand of connective tissue of about $1 \mathrm{~cm}$ thick and ventrally by a lip-like extension of the melon. The left vestibular sac itself reaches to about 3 $\mathrm{cm}$ rostrad of this connection. No separation of the lumina of left and right vestibular sac could be traced.

In Kogia the confluence of the vestibular system seems to be due to an outgrowth of the right vestibular sac across the midline and suppression of the left one. In Inia, however, both vestibular sacs seem to be well developed and the protrusion of the rostral wall of the vestibule in or just above the level of the orifices to the vestibular sacs causes this confluence.

The dorsal aspect of the whole vestibular area is surprisingly symmetrical, contrary to Mead's observation (fig. 1). Furthermore, the rostral aspect is fairly symmetrical though there is a slight difference in the level of left and right vestibular sac in the communication area (fig. 2). The vestibular system nearly covers the total maxillary area dorsal to the orbits; the whole system is somewhat dome-shaped and slopes slightly in rostroventral direction (fig. 3). The walls of the airsac system are somewhat wrinkled, as is normally found in odontocetes, indicating its extensibility.

Deep to the level of the vestibule, the nasal passage runs as a rostrocaudally flattened tube to the bony nares. In its caudal wall the slit-like orifice to the nasofrontal diverticula is found, just ventrally to the blowhole ligaments which normally stretch from the caudomesial border of the caudal extension of the maxillary bones towards the nuchal crests. These diverticula are somewhat laterally expanded, contrary to the condition found in Pontoporia. In Inia, in the dorsal wall of this diverticulum, I found a transverse septum partly dividing the air sac into two compartments lying behind each other. A similar condition though far more developed has been described for Phocoena phocoena (see Schenkkan, 1973).

Rostral parts are tubular and relatively small,

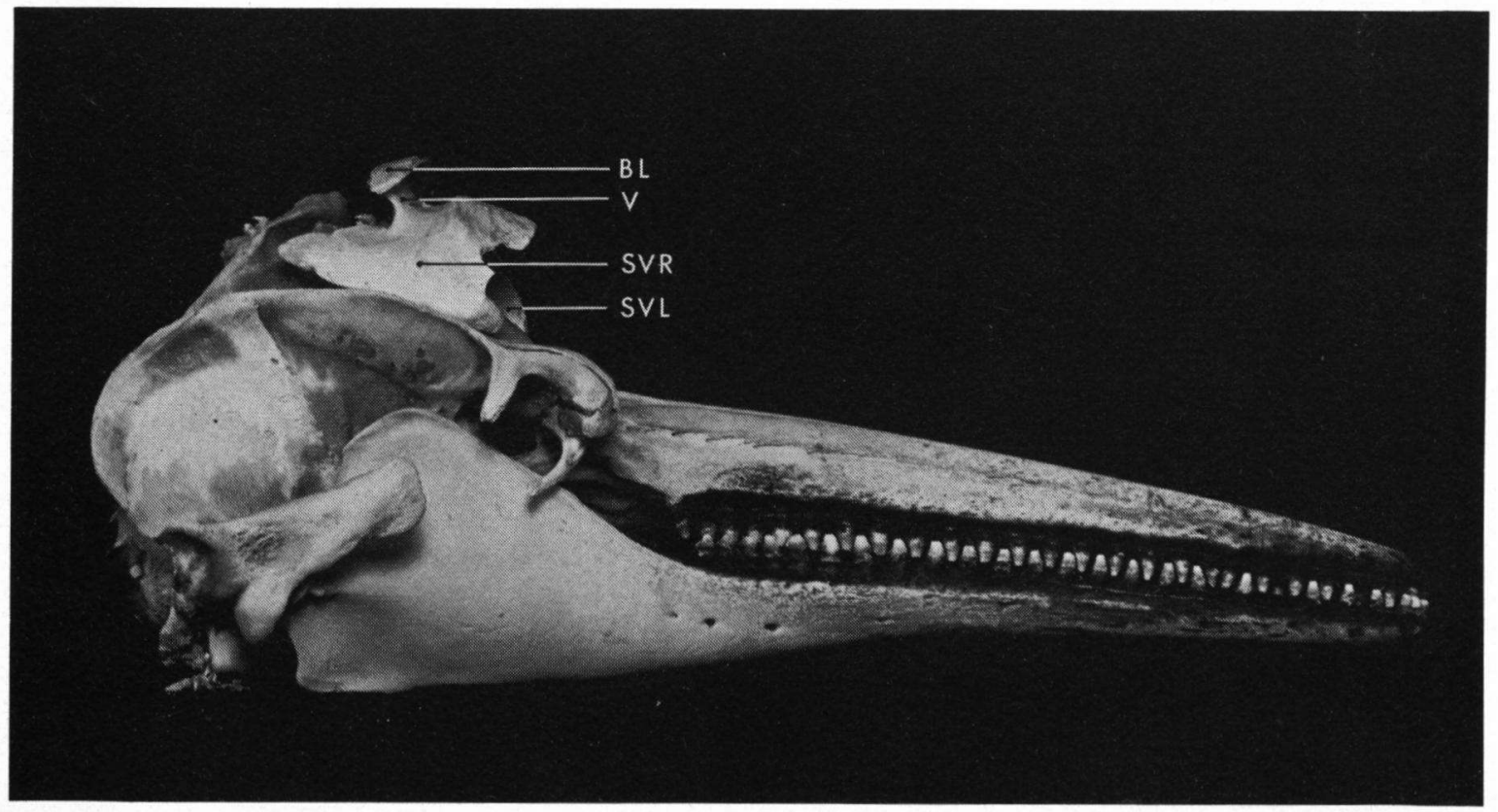

Fig. 3. Lateral aspect of the silicone cast mounted on the same skull as in fig. 1. Photograph: S. van Mechelen. $B L=$ blowhole; $S V L=$ left vestibular sac; $S V R=$ right vestibular sac; $V=$ vestibule. 


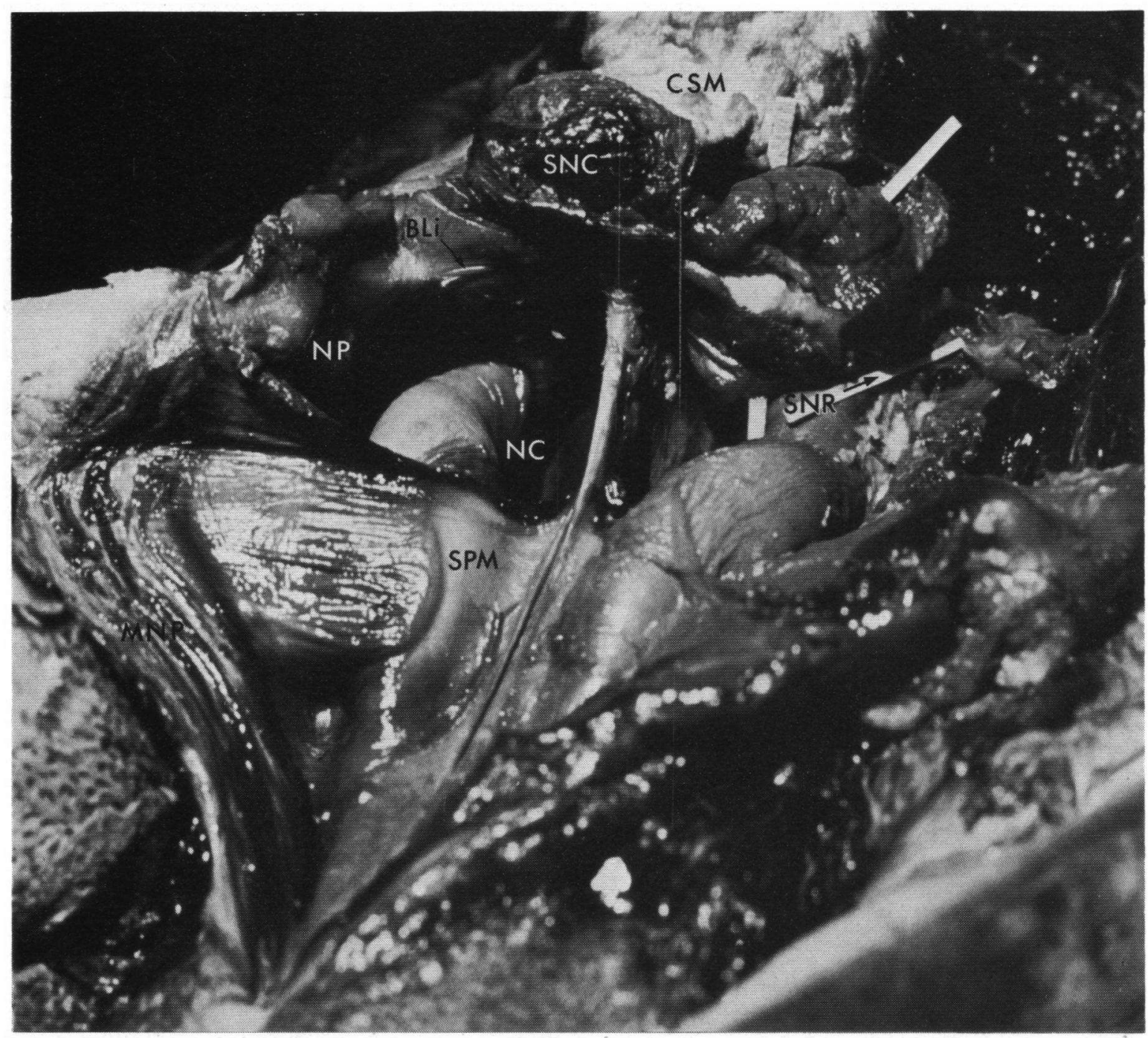

Fig. 4. Deep aspect of the nasal system of an albino Inia geoffrensis. Strips of paper are indicating the passage to the left nasof rontal sac. Photograph: J. Herforth.

$\mathrm{BLi}=$ blowhole ligament; $\mathrm{CSM}=$ supramaxillary crest; $\mathrm{MNP}=$ nasal plug muscle; $\mathrm{NC}=$ nasal canal; $\mathrm{NP}=$ nasal plug; $\mathrm{SNC}$ $=$ caudal section of nasofrontal sac; $\mathbf{S N R}=$ rostral section of nasofrontal sac; $S P M=$ premaxillary sac.

measuring about $11 / 2 \mathrm{~cm}$ in length on both sides and also showing a symmetrical configuration in the nasal system. In all specimens I dissected no accessory sacs could be traced, contrary to Mead's (1975) findings. As expected, the nasal plugs appear to be bulbous and lack lateral liplike extensions. The premaxillary air sacs are relatively broad and extend also over the parts of the premaxillary bones lateral to the bony nares. In deflated state their lumen is occluded nearly completely by the dorsal swellings of the premaxillary bones (fig. 4), just rostrad of the nares. This is also found in Pontoporia though less conspicuous.

Although not pertaining to the study of the nasal cavities, it has to be noted that the symmetry of the skull of Inia in the region of the nares is striking and unique in the whole suborder of the odontocetes, where specifically the bones of the right side are always larger than those of the left side causing a slight displacement of the nares to the left. Observing the complete skull from above (fig. 1), it is obvious that the axis of the rostrum does not lie in the 
same plane with the foramen magnum in that it is not continuous with the axis of the vertebral column (see also Slijper, 1936).

\section{DISCUSSION}

The mechanism and site of sound production is in debate and opinion is divided between two main possible systems. Certain authors maintain that all sounds are generated in the most distal part of the nasal apparatus, e.g. Evans \& Prescott (1962), Norris (1964), Norris \& Evans (1967) and Mead (1975). Others consider at least the main source as being laryngeal, though other structures might possibly be involved in the production of various sounds that have a communicative meaning or are emotional expressions, see e.g. Lilly (1961), Purves (1966), Schenkkan (1973), Schenkkan \& Purves (1973) and Purves \& Pilleri (1973).

Norris et al. (1971) concluded that chirps were monitored at the left nasal plug, and clicks, used for echolocation, at the lateral lip of the right nasal plug. Since in Physeteridae, Hyperoodontidae and Platanistidae the nasal plugs are bulbous structures lacking lateral flap-like extensions, Purves \& Pilleri (1973), Schenkkan \& Purves (1973) and Schenkkan (1972) thought that at least in these families another mechanism must be operating. Moreover, it seems to be reasonable that when the nasal plugs are seated, the lateral lip-like structures as found in Delphinidae act as one-way valves (Schenkkan, 1973). Purves (1966) concluded that by way of relaxation oscillations, the apex of the larynx is highly suitable for phonation, while sounds produced at that site are easily transmitted to the rostrum where at its apex the emission of most sounds can be traced. Phonation and emission in this way avoids great discontinuity in the density of the sound path so that reflection is minimized.

Mead (1975) concluded from the discovery of muscle fibres associated with the diagonal membranes, that these membranes are suitable to subserve the function of phonation. In his opinion these structures permit the higher velocities of airflow with restricted quantities of air needed for this type of phonation. To my mind, these membranes act as one-way valves preventing air to be pressed alongside the nasal plugs upwards and only when the plugs are not com- pletely seated, sounds may be produced by passing air along the edges of the membranes; however, this will interfere with the sealing mechanism of the nasal passage (Schenkkan, 1973). Moreover, Mead (1975) also considered that it is advantageous to have a large reserve volume on either side of the phonation site to minimize the necessity for recycling the air. This hypothesis does not fit for the diagonal membranes when the plugs are seated.

The only remaining possibility is the larynx, a structure which is strikingly uniform within the whole order of cetaceans. Moreover, phonation at its apex does not interfere with the sealing mechanism of the nasal passage at all. The only primary function for the whole airsac system above the level of the nasal plugs has to be a sealing function, though a secondary function in reflecting sounds that are transmitted from below might be involved. However, in my opinion reflection of these sounds in rostral direction being of acoustic significance is overestimated. Prevention of transmission of these sounds in the direction of receiving structures as the tympanic bulla, meatus etc. might be of equal or even greater importance.

\section{LITERATURE}

ANDERSON, J., 1878. Anatomical and zoological researches: comprising an account of the zoological results of the two expeditions to Western Yunnan in 1868 and 1875; and a monograph of the two cetacean genera, Platanista and Orcella. I, Text: vii-xxv, 1-985, I map; II. Plates: $i-v i$, pls. I-LXXXI, XIIIA, XXVA, LXXVA, LXXVB, i- $x i$, 1-29 (B. Quaritch, London).

BAer, K. E. VoN, 1826. Die Nase der Cetaceen. Isis, Jena, 1826: $811-847$.

BeDdARD, F. E., 1915. Contributions to the knowledge of the anatomy of the Sperm Whale (Physeter macrocephalus) based upon the examination of a young foetus. Ann. Durban Mus., 1 (2): 107-124, pl. VIII.

,- 1919 . Further contributions to the anatomy of the Sperm Whale (Physeter macrocephalus) based upon an examination of two additional foetus. Ann. Durban Mus., 2 (4): 129-148, pl. XXIII.

Benham, W. Blaxland, 1901. On the anatomy of Cogia breviceps. Proc. zool. Soc. Lond., 1901 (2): 107-134, pls. VIII-XI.

BURmeister, G., 1867. Descripcion de cuatro especies de delphinides de la costa Argentina en el Océano Atlántico. An. Mus. publ. B. Aires, 1 (9): $367-445$, pls. XXIXXVIII. 
Caldwell, M. G., D. K. Caldwell \& W. E. Evans, 1966. Preliminary results of studies on the sounds and associated behavior of captive Amazon freshwater Dolphins, Inia geoffrensis. Proc. ann. Conf. Biol. Sonar, 3: 178-185.

Caldwell, D. K., J. H. Prescott \& M. C. Caldwell, 1966. Production of pulsed sounds by the Pigmy Sperm Whale Kogia breviceps. Bull. Sth. Calif. Acad. Sci., 65 (4): 245-248.

Carlsson, A., 1888. Zur Anatomie des Hyperoodon diodon. Bih. K. svenska Vetensk.-Akad. Handl., (4) 13 (7): 1-25, pls. I-III.

DANOIS, ED. [LE], 1910. Recherches sur l'anatomie de la tête de Kogia breviceps Blainv. Archs. Zool. exp. gén., (5) 6: 149-174, pls. V-VIII.

-, 1911. Description d'un embryon de Grampus griseus Gray. Archs. Zool. exp. gén., (5) 8: 399-420, pls. VIII-IX.

DijkgraAF, S., 1943. Over een merkwaardige functie van den gehoorzin bij vleermuizen. Versl. gewone Vergad. Afd. Natuurk. K. ned. Akad., 52 (9): 622-627.

Evans, W. E. \& J. H. Prescott, 1962. Observations on the sound production capabilities of the Bottlenosed Porpoise: A study of whistles and clicks. Zoologica, N. Y., 47: 121-128.

Evans, W. E., W. W. Sutherland \& R. C. Beil, 1964. The directional characteristics of delphinid sounds. In: W. N. Tavolga ed., Marine bio-acoustics: 353-372 (Pergamon Press, Oxford/London/New York/Paris).

FLeischer, G., 1973. On structure and function of the middle ear in the Bottlenosed Dolphin (Tursiops truncatus). Proc. ann. Conf. Biol. Sonar Diving Mammals, 9: 137-179.

Fraser, F. C., 1947. Sound emitted by dolphins. Nature, Lond., 160: 759.

Fraser, F. C. \& P. E. Purves, 1954. Hearing in cetaceans. Bull. Br. Mus. nat. Hist. (Zool.), 2 (5): 101-114, pls. IV-V.

$-\&-, 1960$. Hearing in cetaceans. Evolution of the accessory air sacs and the structure and function of the outer and middle ear in recent cetaceans. Bull. Br. Mus. nat. Hist. (Zool.), 7 (1): 1-140, figs. 1-34, pls. [I], I-LIII.

Griffin, D. R., 1958. Listening in the dark. The acoustic orientation of bats and man: $1-413$ (Yale Univ. Press, New Haven).

Griffin, D. R. \& R. Galambos, 1940. Obstacle avoidance by flying bats. Anat. Rec., 78: 95.

- \&,- 1941 . The sensory basis of obstacle avoidance by flying bats. J. exp. Zool., 86 (3): 481-506.

GruHL, K., 1911. Beitrāge zur Anatomie und Physiologie der Cetaceennase. Jena Z. Naturw., 47 (3): 367-414.

HaNKe, H., 1914. Die Nase von Mesoplodon bidens. In: W. KüKENTHAL, Untersuchungen an Walen, II. Jena Z. Naturw., 51 (1): 112-122.

Hinton, M. A. C., 1936. Some interesting points in the anatomy of the freshwater dolphin Lipotes and its allies. Proc. Linn. Soc. Lond., 148 (3): 183-186.

HUBER, E., 1930. Evolution of facial musculature and cutaneous field of Trigeminus. Q. Rev. Biol., 5: 133-188, $389-437$.

-, 1934. Anatomical notes on Pinnipedia and Cetacea. Publs. Carnegie Instn., 447: 105-136.

HunTER, J., 1787. Observations on the structure and oeconomy of whales. Phil. Trans. R. Soc., 77: 371-450, pls. XVI-XXIII.
Kernan, J. D. JR. \& H. von Schulte, 1918. Memoranda upon the anatomy of the respiratory tract, foregut, and thoracic viscera of a foetal Kogia breviceps. Bull. Am. Mus. nat. Hist., 38: 231-267.

LAWRENCE, B. \& W. E. SChevill, 1956. The functional anatomy of the delphinid nose. Bull. Mus. comp. Zool. Harv., 114 (4): 101-151, figs. $1-30$.

LILLY, J. C., 1961. Man and dolphin: 1-312 (Doubleday \& Co., Garden City).

Major, D. J., 1672. De anatome Phocaenae. Miscnea cur. med.-phys., 3: 1-22.

MEAD, J. G., 1972. Anatomy of the external nasal passages and facial complex in the Delphinidae (Mammalia: Cetacea): 1-208 (mimeographed thesis, University of Chicago).

- , 1975. Anatomy of the external nasal passages and facial complex in the Delphinidae (Mammalia: Cetacea). Smithson. Contr. Zool., 207: i-iii, 1-72.

Moris, F., 1969. Etude anatomique de la région céphalique du Marsouin, Phocaena phocaena L. (Cétacé Odontocète). Mammalia, 33 (4): 666-705, figs. 1-27, pls. XXXI-XXXIV.

Murie, J., 1870. On Risso's Grampus, G. rissoanus (Desm.). J. Anat. Physiol. Lond., 5: 118-138, pl. V.

-, 1871. Notes on the White-beaked Bottlenose, Lagenorhynchus albirostris, Gray. J. Linn. Soc. (Zool.), 11: 141-153, pl. V.

,- 1873 . On the organization of the Caaing Whale, Globiocephalus melas. Trans. zool. Soc. Lond., 8 (4): 235-301, pls. XXX-XXXVIII.

NoRRIS, K. S., 1964. Some problems of echolocation in cetaceans. In: W. N. TAvolgA ed., Marine bio-acoustics: 317-336 (Pergamon Press, Oxford/London/New York/Paris).

,- 1969. The echolocation of marine mammals. In: H. T. ANDERSEN ed., The biology of marine mammals: $391-423$ (Academic Press, New York/London).

Norris, K. S., K. J. Dormer, J. PegG \& G. J. Liese, 1971. The mechanism of sound production and air recycling in porpoises: a preliminary report. Proc. ann. Conf. Biol. Sonar, 8: 1-11, figs. 1-4.

Norris, K. S. \& W. E. Evans, 1967. Directionality of echolocation clicks in the Roughtooth Porpoise, Steno bredanensis (Lesson). In: W. N. Tavolga ed., Marine bioacoustics, II: 305-316 (Pergamon Press, Oxford/London/ New York/Paris).

Norris, K. S., J. H. Prescott, P. V. Asa-Dorian \& P. PerKINs, 1961. An experimental demonstration of echo-location behaviour in the porpoise, Tursiops truncatus (Montagu). Biol. Bull. mar. biol. Lab. Woods Hole, 120: $163-176$.

Pouchet, G. \& H. Beauregard, 1885. Note sur "l'organe des spermaceti". C. r. Séanc. Soc. Biol., (8) 2: 342-344.

Purves, P. E., 1966. Anatomical and experimental observations in the cetacean sonar system. In: R. G. BUSNEL ed., Systèmes sonars animaux; biologie et bionique: 197-270 (Symp. Frascati).

Purves, P. E. \& G. Pilleri, 1973. Observations on the ear, nose, throat and eye of Platanista indi. Invest. Cetacea, 5: 13-57, pls. I-XVIII.

Purves, P. E. \& W. L. van Utrecht, 1963. The anatomy and function of the ear of the Bottle-nosed Dolphin Tursiops truncatus. Beaufortia, 9 (111): 241-256. 
RAy, J., 1671. An account of the dissection of a porpess. Phil. Trans. R. Soc., 6 (76): 2274-2279.

ReysenbaCh DE HAAN, F. W., 1956. De ceti auditu: over de. gehoorzin bij de walvissen: $1-160$ (Schotanus \& Jens, Utrecht).

SChEnkKan, E. J., 1971. The occurrence and position of the "connecting sac" in the nasal tract complex of small odontocetes (Mammalia, Cetacea). Beaufortia, 19 (246): $37-43$.

,- 1972 . On the nasal tract complex of Pontoporia blainvillei (Gervais \& d'Orbigny, 1844) (Mammalia, Odontoceti). Invest. Cetacea, 4: 83-90, pls. I-II.

,- 1973 . On the comparative anatomy and function of the nasal tract in odontocetes (Mammalia, Cetacea). Bijdr. Dierk., 43 (2): 127-159.

Schenkkan, E. J. \& P. E. Purves, 1973. The comparative anatomy of the nasal tract and the function of the spermaceti organ in the Physeteridae (Mammalia, Odontoceti). Bijdr.
Dierk., 43 (1): 93-112.

Sibson, F., 1848. On the blow-hole of the porpoise. Phil. Trans. R. Soc., 1848 (7): 117-123, pl. VII.

SliJPer, E. J., 1936. Die Cetaceen. Vergleichend-anatomisch und systematisch. Ein Beitrag zur vergleichenden Anatomie des Blutgefäss-, Nerven- und Muskelsystems, sowie des Rumpfskelettes der Säugetiere, mit Studien über die Theorie des Aussterbens und der Foetalisation. Capita Zool., 7: 1-590 (Ph. D. Thesis, University of Utrecht; M. Nijhoff, The Hague).

TYson, E., 1680. Phocoena, or the anatomy of a porpess, dissected at Gresham Colledge; with a preliminary discourse concerning anatomy, and a natural history of animals: $1-48$, pls. I-II (B. Tooke, London).

WATSON, M.\& A. H. Young, 1879. The anatomy of the Northern Beluga (Beluga catodon, Gray; Delphinapterus leucas, Pallas) compared with that of other whales. Trans. $R$. Soc. Edinb., 29 (1): 393-435, pls. VII-VIII.

Received: 1 June 1976 